\title{
Influence of the composition and structure of modified landscapes on abundance of two marsupials during the dry season
}

\author{
Bárbara Cruz-Salazar ${ }^{*}$, Lorena Ruiz-Montoya ${ }^{1}$, Darío Navarrete-Gutiérrez ${ }^{1}$ y Luis-Bernardo Vázquez ${ }^{1}$ \\ ' El Colegio de la Frontera Sur, Departamento de Conservación de la Biodiversidad. Carretera Panamericana s/n. Barrio de María \\ Auxiliadora, San Cristóbal de Las Casas, Chiapas, 29290, México. Email: bcruz@ecosur.edu.mx (BCS), Iruiz@ecosur.mx (LRM), \\ dnavarre@ecosur.mx (DNG),l.b.vazquez@gmail.com (LBV). \\ "Corresponding author
}

\begin{abstract}
Changes in the landscape due to habitat loss and fragmentation interact with ecological processes of populations, and define the local population abundance. We evaluated the relationship between the abundance of two common marsupials, Didelphis marsupialis (common opossum) and Didelphis virginiana (Virginia opossum), and landscape features in different levels of disturbance at Chiapas, the Highlands and the Central Depression. The goal was to identify effects of changes in the landscape in their populations. Based on the biological characteristics of $D$. marsupialis and $D$. virginiana our expectation was to observe higher abundance of opossums in areas with intermediate disturbance. At the same time, establish a relationship between the landscape composition and the abundance of both species. We placed 48 Tomahawk traps in three disturbance levels of the landscape. Within each disturbance level we obtained the structure and composition of the landscape. The abundance of each species was considered as the number of individuals captured. A relative abundance index was estimated from individuals captured by night traps. The influence of the disturbance levels, the landscape, structure, and composition in the abundance of each species was evaluated using multiple regression and generalized lineal model. The average abundance of Didelphis spp. was higher in the Central Depression (5.56 individuals, SD $=4.82$ ). Didelphis marsupialis was captured only in low disturbance with an average of 0.56 individuals ( $S D=1.04$; Figure $2 a)$, while $D$. virginiana was captured in the three levels of disturbance with an average of 3.56 individuals ( $S D=3.88$; Figure $2 b$ ). The presence of $D$. marsupialis was influenced by the number of patches (NP; $P=0.003$ ), while for $D$. virginiana landscape index was not associated with its presence (Table 2). Our results suggest that the abundance of $D$. marsupialis and $D$. virginiana was not influenced by level of disturbance. However, $D$. marsupialis was related to the number of patches and conserved areas; while $D$. virginiana was not affected by the landscape attributes evaluated, i. e. composition and configuration, indicating that Virginia opossum can established relatively abundant populations in landscapes highly disturbed. This study contributes to the understanding of the effects of changes in the landscape in common species in Mexico due to human activities.
\end{abstract}

Key words: common species; Didelphis; habitat loss; landscape; landscape fragmentation; mammals.

Los cambios en el paisaje debido a la pérdida y fragmentación del hábitat interactúan con procesos ecológicos poblacionales y definen la abundancia poblacional local. Se evaluaron las relaciones entre la abundancia de dos marsupiales comunes, Didelphis marsupialis (tlacuache común) y Didelphis virginiana (tlacuache de Virginia), y los atributos del paisaje en diferentes niveles de disturbio en Chiapas, Los Altos y la Depresión Central. El objetivo fue identificar efectos de cambios del paisaje sobre sus poblaciones. Con base en las características biológicas de $D$. marsupialis y $D$. virginiana, nuestra hipótesis fue observar una mayor abundancia de tlacuaches en áreas con disturbio intermedio. Al mismo tiempo, establecer una relación entre la composición del paisaje y la abundancia de ambas especies. Se colocaron 48 trampas Tomahawk en tres niveles de disturbio. De cada nivel de disturbio se obtuvo la estructura y composición del paisaje. La abundancia por especie fue considerada como el número de individuos capturados. El índice de abundancia relativa fue estimado mediante los individuos capturados por trampas noches. La influencia del nivel de disturbio, paisaje, composición y estructura en la abundancia para cada especie se estimó a partir de regresiones múltiples y modelos lineales generalizados. La abundancia promedio de Didelphis sp. fue mayor en la Depresión Central (5.56 individuos, $\mathrm{DE}=4.82$ ). Didelphis marsupialis fue capturada solo en condiciones de bajo disturbio con un promedio de 0.56 individuos ( $D E=1.04$; Figura $2 \mathrm{a}$ ), mientras que $D$. virginiana fue capturada en los tres niveles de disturbio con un promedio de 3.56 individuos ( $\mathrm{DE}=3.88$; Figura $2 \mathrm{~b}$ ). El número de parches (NP) influyó en la presencia de $D$. marsupialis $(P=0.003)$, en tanto que para $D$. virginiana ningún índice del paisaje se asoció con su presencia (Tabla 2). Nuestros resultados sugieren que el nivel de disturbio no influye en la abundancia de $D$. marsupialis y $D$. virginiana. Sin embargo, D. marsupialis se relacionó con el número de parches y áreas conservadas; en tanto que $D$. virginiana no fue afectada por los atributos del paisaje evaluados, i. e. composición y configuración, indicando que el tlacuache de Virginia puede establecer poblaciones relativamente abundantes en paisajes altamente perturbados. Este estudio contribuye al conocimiento de los efectos de los cambios en el paisaje por actividades humanas en especies comunes en México. 


\section{Introduction}

Landscape composition influences ecological processes at local and population levels (MacAlpine et al. 2015). It is now possible to obtain a quantitative characterization of landscape attributes and, with this, assess the effects of landscape modification on diversity patterns at different geographical scales (Fan and Myin 2014). Landscape heterogeneity plays a role in the complexity of biotic and abiotic interactions in a particular area. The landscape unit has two basic attributes: composition and configuration. Landscape composition involves the number of components (types of coverage) and the relative contribution of each, while configuration denotes the spatial arrangement of those components within the landscape. Modified landscapes are a mixture of natural and anthropogenic components, characterized by a high heterogeneity derived primarily from changes in land use (Flick et al. 2012); however, landscapes where natural components have been completely eliminated, such as cities and towns, show very low heterogeneity and offer precarious conditions for the establishment of wild species (Schooley and Branch 2011; Garmendia et al. 2013).

Changes in the geographical distribution, abundance and isolation of populations of wild species are among the most noticeable consequences of landscape modification (Hughes et al. 2003; Lindenmayer et al. 2008; Spear et al. 2010). From an ecological perspective, ecosystem disturbance and fragmentation are considered to be particularly detrimental for many terrestrial mammals, since these are highly vulnerable to land-use changes (Gorresen and Willig 2004). In contrast, it is believed that environments modified as a result of human activities provide a greater availability and quality of resources for disturbance-tolerant mammals, thus leading to an increase in their local abundance and the expansion of their populations (Gaston et al. 2000; Cruz-Salazar et al. 2014). Both approaches consider that population viability in modified landscapes depends on the intensity and permanence of landscape modification. The establishment of urban centers and large monoculture areas are the anthropogenic disturbances with the strongest effect on the permanence of wild species (Braunisch et al. 2010; Bruggeman et al. 2010; Schooley and Branch 2011; Garmendia et al. 2013).

Abundance is a population attribute of species that responds immediately to the effect of landscape modification in both generalist and specialist species (Gaston 2010). Generalist species are able to partially or entirely replace their original habitat by a modified one (Lindenmayer et al. 2000); therefore, landscape fragmentation and habitat loss are considered to have no negative effects on their populations (Markovchick-Nicholls et al. 2007). Didelphis marsupialis (common opossum) and D. virginiana (Virginia opossum) are common and extremely adaptable marsupials, being both generalists and opportunistic (Adler 1997; Cabello 2006; Markovchick-Nicholls et al. 2007). Both species have a high dispersal capacity $(5.7 \mathrm{~km}$ for $D$. virginiana, and $>1 \mathrm{~km}$ for $D$. marsupialis; Gillette 1980; Sunquist et al. 1987), are promiscuous and nomadic, and thus maintain genetically related populations even in fragmented landscapes (Beatty et al. 2012; Hennessy et al. $\underline{2015}$.

Despite the ecological importance of these marsupials (e. g., for seed dispersal, regulation of insect abundance, potential preys) and their relevance for conservation as members of a mammal group scarcely represented in Mexico (Medina-Romero et al. 2012), little progress has been made in the knowledge of their abundance and the effects of landscape structure and composition in Mexico. Studies on D. marsupialis have focused on the southern part of its distribution range (Central and South America; Adler et al. 1997; Cáceres and Monteiro-Filho 1998; Kelly and Caro 2003; Orjuela and Jiménez 2004; Lambert et al. 2005; Cabello 2006). In the case of D. virginiana, studies have focused on the northern portion of its distribution range (North America; Kanda et al. 2005; Markovchick-Nicholls et al. 2007; Kanda et al. 2009; Beasley et al. 2010; Beatty et al. 2012; Wright 
et al. 2012; Beatty et al. 2014; Hennessy et al. 2015). In Mexico, general life history characteristics of its (Colchero et al. 2005; Zarza and Medellín 2005), feeding habits and reproduction (OcegueraGonzález and González-Romero 2008), bar codes (Cervantes et al. 2010), phylogeny (MedinaRomero et al. 2012), local abundance and genetic diversity (Cruz-Salazar et al. 2014; 2016) have been studied.

The aim of this study was to analyze the effect of the physical configuration and structure of landscape on the abundance of $D$. marsupialis and $D$. virginiana, with particular emphasis on the extent of landscape disturbance, as well as to determine whether their abundance increases with the level of landscape disturbance and how this varies for each species. Based on previous studies that identify D. marsupialis and D. virginiana as synanthropic species (Hennessy et al. 2015) and that the greatest diversity of food and shelter occurs in moderately disturbed areas (Kanda et al. 2009; Beatty et al. 2014), an additional aim was to establish the relationship between opossum abundance and landscape composition.

\section{Materials and Methods}

Study area. The study was conducted in two landscapes located in two distinct regions of the State of Chiapas: the Highlands (Los Altos de Chiapas) and the Central Depression (Depresión Central; Figure 1). Dominant plant communities in the Highlands are pine (Pinus) and oak (Quercus) forests (Ramírez-Marcial et al. 2001; González-Espinosa et al. 2005; González-Espinosa et al. 2008). Oak forests are constantly exposed to fragmentation and replacement by cropland (maize, vegetables, flowers, fruit trees). These changes produce a landscape composed of secondary plant communities, extensive livestock raising and human settlements (González-Espinosa et al. 2005). The dominant vegetation in the Central Depression is tropical, low-stature deciduous forest and medium-stature semi-evergreen forest (Rocha-Loredo et al. 2010). The main land uses include extensive livestock raising, fuelwood collection, agriculture (maize, vegetables, fruit trees) and induced grassland (Ramírez-Albores 2010). These landscapes were selected based on the knowledge of their respective levels of mammalian diversity (Naranjo et al. 2013), the presence of both opossum species (Naranjo et al. 2005), and the fragmentation processes associated with land-use change (González-Espinosa et al. 2005; Rocha-Loredo et al. 2010).

Disturbance levels. Three disturbance levels were selected in each landscape based on the matrix composition: L1, low disturbance, area consisting of a matrix of relatively continuous forest, with little or no influence of anthropogenic activities, or where such activities had been suspended for at least the last 15 years. The vegetation is undergoing a natural regeneration process. L2, moderate disturbance, this area includes both natural and anthropogenic elements, the matrix comprises productive activities, fragments of urban areas (housing, infrastructure), patches of native vegetation and vegetation in an early successional stage (acahual). L3, high disturbance, composed of an almost completely urbanized matrix plus areas with anthropogenic infrastructure (buildings, recreational activities, occupational activities, education and/or transportation). These areas include introduced and ornamental vegetation. From each disturbance level, three sampling sites or landscape windows were obtained (3 replicates $\times 3$ disturbance levels per landscape), provided these shared similar characteristics in terms of land use and fragmentation.

In the Highlands, low-disturbance (L1) sampling sites were Cerro Corral de Piedra (CP), Cerro Huitepec Biological Reserve (RH), and Moxviquil Biological Reserve (RM). Moderate disturbance (L2): El Aguaje village (PA), San Isidro Las Huertas village (SI), and village km 36 on the Tuxtla Gutiérrez-San Cristóbal de Las Casas highway, Chiapas (PK). High disturbance (L3): San Cristobal de Las Casas Municipal Cemetery (PM), San Cristóbal de Las Casas Municipal Sports Center (CD), and Colegio de la Frontera Sur, in the same municipality (EC; Figure 1a).

In the Central Depression, the low-disturbance (L1) sampling sites were: Coquelexquitzán hill (CC), Ravine km-12 on the Tuxtla Gutiérrez-San Cristobal de Las Casas highway, Chiapas (CA), 
and La Pera, Berriozábal (LP). Moderate disturbance (L2): Perseverancia Ranch (RP), al Sol Ranch (RS) and the Tuxtla Gutierrez campus of Instituto Tecnológico de Monterrey, Chiapas (TM). High disturbance (L3): Oriente Park (PO), Joyo Mayu Park (PJ), and Tuxtla Gutierrez Regional Technology Center, Chiapas (TR; Table 1; Figure 1b).

Field work. In each sampling site, 48 sardine-baited $(15.2 \times 15.2 \times 48 \mathrm{~cm})$ Tomahawk traps were placed in a radial arrangement, separated by $20 \mathrm{~m}$ from each other, within a total area of $289.5 \mathrm{ha}$ for four consecutive nights (Adler et al. 1997). Sampling was carried out from March through June 2011 and from March through June 2012. The sampling effort was: 192 trap-nights per site, 576 trap-nights per disturbance level (in each landscape), and 1,728 trap-nights per landscape. Each specimen captured was determined taxonomically based on its length of the dark area of the tail, cheek and pectoral coloration, (Gardner 1973; McManus 1974; Aranda 2000). The standard biological attributes (i. e., sex, external measurements, weight) of each specimen were determined, along with its geographical sampling location; the specimens were subsequently released.

Satellite imagery classification. To evaluate the structure and composition of each landscape, SPOT 5 HRG satellite images were used: Two 2008 scenes for the Highlands and two 2011 scenes for the Central Depression. The spatial resolution of these multispectral images was $10 \mathrm{~m}$. The images were registered using an orthorectification standard in order to analyze multiple images in a mosaic and make them compatible with other spatial data (Cuartero and Felicísimo 2003). Images were orthorectified using their orbital parameters and a $15 \mathrm{~m}$ Digital Elevation Model (DEM) by INEGI for the study area. The Nearest Neighbor method was used for resampling both the images and the DEM; geoidal undulations were corrected based on the central coordinates of each image. The Mexican Gravimetric Geoid (GGM10) model and the current official reference frame (ITRF08, epoch 2010.0) mandated by the Instituto Nacional de Estadística y Geografía (INEGI $\underline{2013}$ ) were used. The absolute accuracy of geoid heights in the GGM10 model was estimated as a $20 \mathrm{~cm}$ (Mean Squared Error). Geoidal undulations for each scene were calculated using the Geoid Height Interpolation System (SIAG v. 1.1) available at INEGI's website (INEGI 2013). Images were orthorectified using the ENVI v. 5.1 (EVIS 2013) software, and a mosaic was built from the spatially corrected images for the two entire areas of interest. Images were visually classified using the interdependent method (FAO 1996) in ArcGIS v. 10.2 (ESRI 2011). For each vegetation coverage and land use type considered in the interdependent classification of satellite images, 74 field trips to the study area were conducted and 234 control points were recorded using the Garmin E-Trex Global Positioning System (GPS) in the Universal Transverse Mercator (UTM) coordinate system. Vegetation types or plant formations were described using the classification proposed by Miranda and Hernández X (1963); other land coverages and uses were described in terms of the INEGI (2012)'s classification. Vegetation types and land uses observed in the Highlands were: oak forest, pine forest, pine-oak forest, oak-pine forest, wetlands, secondary vegetation, grasslands, rainfed agriculture, urban areas and areas devoid of vegetation. For the Central Depression these were: medium-stature semi-deciduous tropical forest, low-stature deciduous tropical forest, water bodies, secondary vegetation, rain-fed agriculture and urban areas.

Landscape Indices. Sampling sites were geographically located in the landscape; afterwards, a circular area of $7.07 \mathrm{~km}^{2}$ and $1.6 \mathrm{~km}$ radius was outlined in each one. Each landscape was characterized by a total of nine sites ( 3 replicates $\times 3$ disturbance levels; Figure 1). Landscape geometry (structure) was described in terms of the number of patches (NP), edge density (ED) and mean shape index (MSI), while landscape composition was evaluated in terms of the Shannon's diversity index (SDI). These indexes were selected because they assess landscape structure and heterogeneity, both of which may influence the abundance of mammals (Lambert et al. 2005; Badii and Landeros 2006; Altamirano et al. 2012; Garmendia et al. 2013; Appendix 1). Landscape 
characterization was carried out with the ArcGIS v. 10.2 software (ESRI 2011). Landscape indexes were calculated using the Patch Analyst plug-in for ArcGIS v. 10.2 (Rempel et al. 2012).

Analysis. Abundance was defined as the number of specimens captured per sampling site; this was considered as the dependent variable for statistical analyses. Additionally, the relative abundance index $(\lambda)$ was calculated based on the number of specimens captured per trap per night (Adler et al. 1997). Potential explanatory variables of the abundance of $D$. marsupialis and $D$. virginiana were disturbance level (low, moderate, high), landscape (the Highlands or Central Depression), landscape structure and composition, and presence of each species. An analysis of variance was carried out to determine the dispersion and treatment of the data obtained. The influence of the disturbance level (low, moderate, high), landscape (the Highlands and Central Depression), and landscape structure on the species abundance was assessed using multiple linear regression and generalized linear models. The relationship between abundance and landscape composition was determined by means of analysis of covariance (ANCOVA) with species as a covariate. To choose the model that best described the data in terms of the influence of predictive factors (i. e. disturbance level, landscape, species, landscape attributes) on abundance, the Akaike Information Criterion (AIC) was used; AIC measures the statistical fit of each model using the formula: $\mathrm{AIC}=-2 \ln (L)+2 K$, where $L$ is the maximum likelihood of the estimated model, and $K$ is the number of parameters in the model; the best model is the one that yields the minimum AIC value (Akaike 1974). Due to the few opossum specimens captured, especially for $D$. marsupialis, generalized linear models were fitted to the opossum presence/absence in each vegetation and land-use type considered. Finally, to determine whether the abundance of one marsupial species depends on the abundance of the other, linear regressions with binomial error were used. All analyzes were performed with the statistical program R v. 3 (Team 2013).
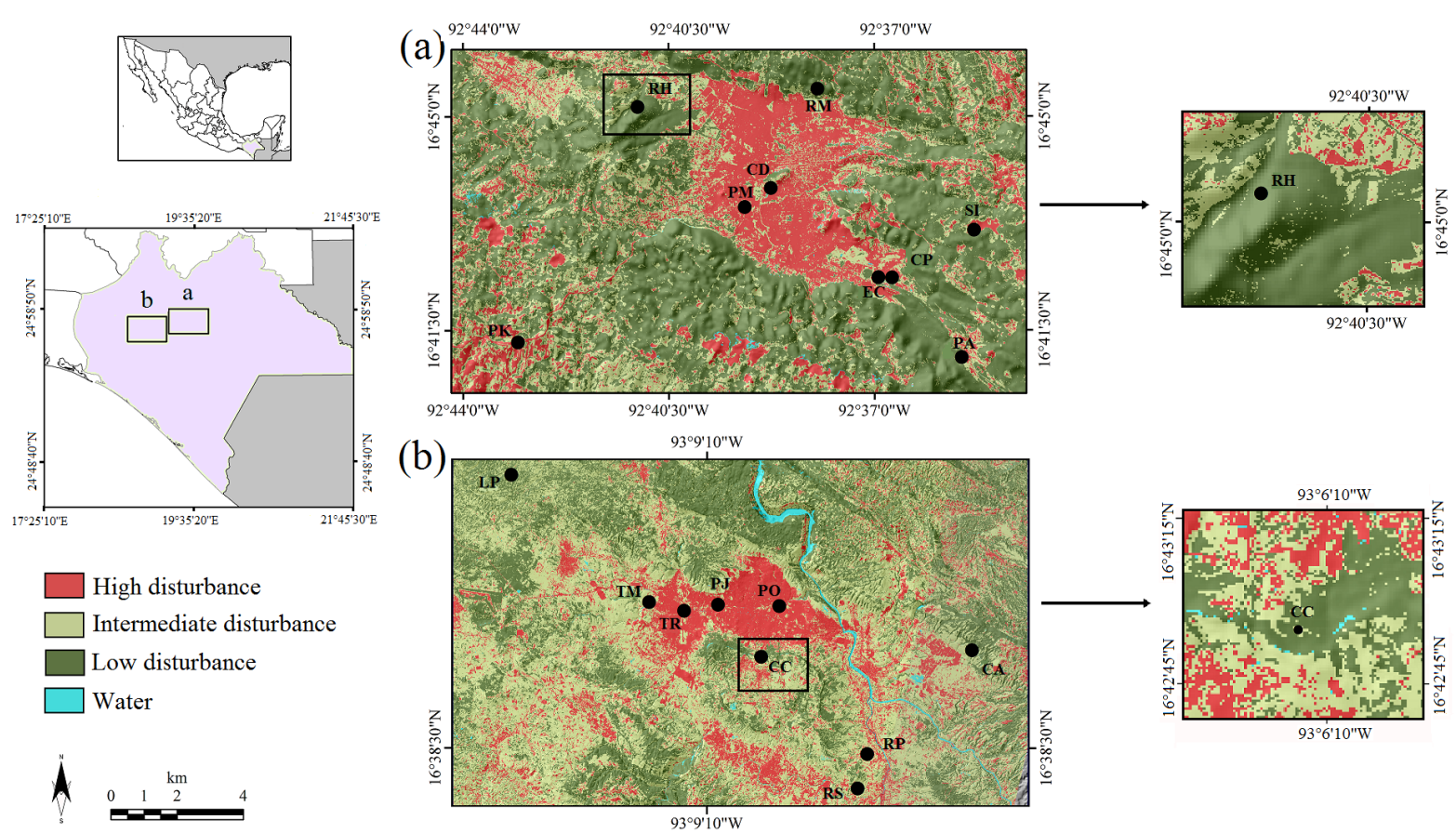

Figure 1. Sampling sites or windows in the landscape for the capture Didelphis marsupialis and Didelphis virginiana in the Highlands (a) and the Central Depression (b) of Chiapas, Mexico. RH = Cerro Huitepec Biological Reserve, RM = Moxviquil Biological Reserve, $\mathrm{CP}=$ Cerro Corral de Piedra, $\mathrm{PA}=\mathrm{El}$ Aguaje village, $\mathrm{SI}=$ San Isidro Las Huertas village, $\mathrm{PK}=$ Village km 36 of the Tuxtla GutiérrezSan Cristobal de Las Casas highway, CD = San Cristobal de Las Casas Municipal Sports Center, EC = Colegio de la Frontera Sur, San Cristobal de Las Casas, PM = San Cristobal de Las Casas Municipal Cemetery, CC = Cerro Coquelexquitzán, CA = ravine km 12 of the Tuxtla Gutiérrez-San Cristóbal de Las Casas highway, LP = La Pera, Berriozábal, RS = Rancho al Sol, RP = Rancho Perseverancia, TM = Tuxtla Gutierrez campus of Instituto Tecnológico de Monterrey, PJ = Parque Joyo Mayu, PO = Parque del Oriente, $\mathrm{Tr}=\mathrm{Tuxtla}$ Gutierrez Regional Technology Center. The identification data (K - J) for the Central Depression images are: 602-316 and 602-317; for The Highlands: 603-316; 603-317; 604-316; 604-317 and 605-317. 


\section{Results}

A total of 73 opossum specimens were captured: 10 D. marsupialis and 63 D. virginiana. The mean abundance by region was 2.56 individuals in the Highlands and 0556 individuals in the Central Depression. D. virginiana was the most abundant species in both landscapes. Four specimens of D. marsupialis and 19 of D. virginiana were captured in The Highlands; six and 44 specimens, respectively, were captured in the Central Depression (Table 1).

The mean opossum abundance, i. e. the total number of specimens captured by disturbance level in both sites was 3.17 for the low level, 3.83 for the moderate level and 5.17 for the high level. In the Highlands, values obtained were 5 for the low level, 0.33 for the moderate level and 2.33 for the high level; in the Central Depression, the corresponding values were 1.33, 7.33 and 8.0, respectively. The mean abundance by species was 0.56 individuals for $D$. marsupialis and 3.56 for $D$. virginiana.

Abundance Distribution of Didelphis marsupialis. This species was captured in sites with high heterogeneity and high number of fragments (Table 1). As for the abundance recorded by disturbance level, in the Highlands only four specimens of $D$. marsupialis were captured in low disturbance (L1) sites, while in the Central Depression three specimens were captured in L1 and L2 (Table 1). The mean relative abundance index ( $\lambda$ )was 0.003 individuals per night, per trap in the Highlands and 0.005 in the Central Depression. By disturbance level, this index was 0.01 in L1 in The Highlands. In the Central Depression, the values for this index were 0.008 in L1 and 0.006 in L2 (Figure 2a).

Abundance Distribution of Didelphis virginiana. The highest abundance was recorded in lowdisturbance sites in the Highlands (11 specimens) and in high-disturbance sites in the Central Depression (24 specimens; Table 1). The mean relative abundance index $(\lambda)$ for each landscape was 0.02 individuals per night per trap in the Highlands and 0.04 in the Central Depression. In particular, at the Highlands 0.03 individuals were recorded in L1, 0.002 in L2 and 0.02 in L3. In the Central Depression, relative abundance figures were $0.002,0.05$ and 0.7 , respectively (Figure $2 b$ ).

Landscape-Abundance Relationship The generalized linear models revealed a significant influence of the number of patches $(p=0.003)$ and edge density $(p=0.02)$ on the presence of $D$. marsupialis (Figure 3a). However, the evaluation of models with AIC showed that NP is the variable that best predicts the presence of this species (Table 2). For D. virginiana no significant relationship was found with any of the landscape characteristics considered (Figure 3b, Table 2). The ANCOVA also found no influence of SDI on the abundance of both species $(p=0.73)$. The linear regression showed no relationship between opossum abundance and disturbance level $(p=0.99)$, but it did reveal a significant relationship between abundance and landscape $(p=0.003)$. Finally, the linear regression with binomial error did not show a significant relationship between the number of $D$. virginiana specimens captured and the total number of opossum specimens captured (Didelphis spp.), in spite of having observed that the abundance of $D$. virginiana increased with the total number of opossum specimens ( $p=0.08$ ).

\section{Discussion}

No relationship was observed between the abundance of $D$. marsupialis and the abundance of $D$. virginiana within the landscape characteristics studied. Contrary to our expectation for species that adaptable to - and even favored by — habitat disturbance by human activities (Naranjo et al. 2013; Hennessy et al. 2015), the abundance of the two opossum species was unrelated to disturbance levels. However, it is worth mentioning that $D$. marsupialis was found only in low disturbance areas, and its occurrence was related to the number of patches; for its part, $D$. virginiana was captured in higher numbers and at all disturbance levels in both areas. The abundance recorded in the Central Depression and the Highlands of Chiapas is consistent with that observed in previous 
(a)

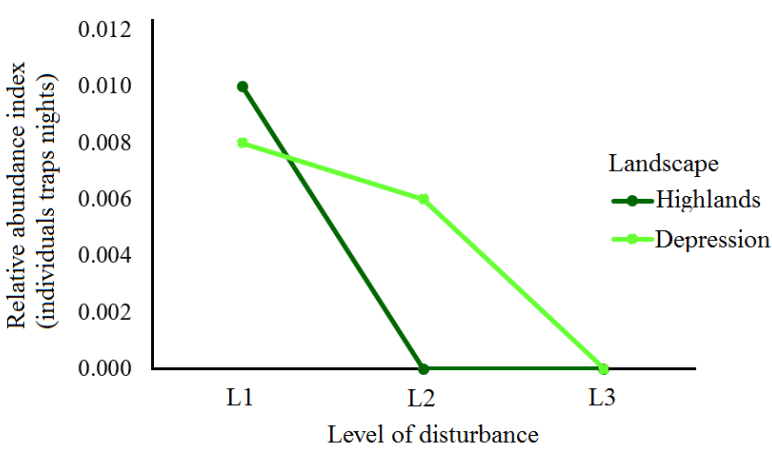

(b)

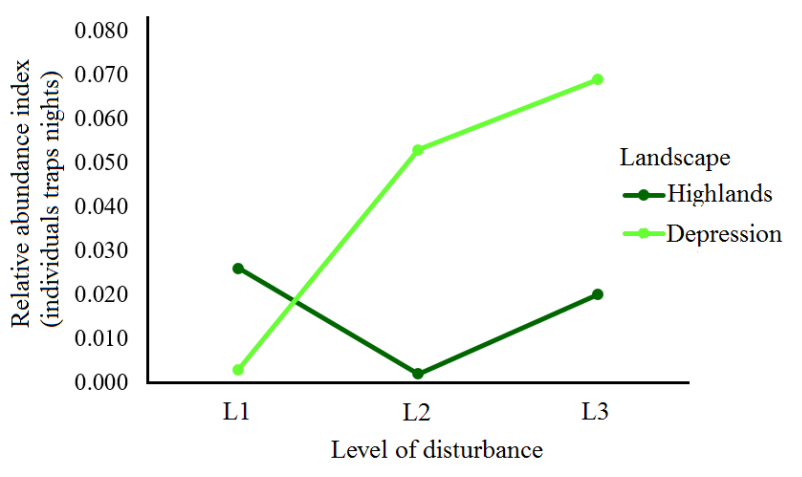

Figure 2. Relative Abundance Index ( $\lambda$ ) for Didelphis marsupialis (a) and D. virginiana (b) according to disturbance levels in the Highlands (High) and the Central Depression (Depression) of Chiapas, Mexico. L1 = low disturbance, L2 = moderate disturbance, L3 = high disturbance.

studies (Cherem et al. 1996; Adler et al. 1997; Cáceres and Monteiro-Filho 1998; Kelly and Caro 2003; Cruz-Salazar et al. 2014). The results suggest that the populations of these marsupials comprise a few individuals in spite of their high reproductive rate and ability to exploit resources derived from human activities. High mortality rates due to factors such as predation, hunting and road collisions may explain the low abundance of $D$. marsupialis and $D$. virginiana in the populations studied (Orjuela and Jiménez 2004; Cabello 2006; Tlapaya and Gallina 2010).

The abundance recorded in the Central Depression was significantly higher than in the Highlands de Chiapas; this could be due to variations in resource availability in each region. the Highlands is dominated by pine-oak forest patches, where diversity is low (González-Espinosa et al. 2008), offering fewer resources to Didelphis spp. In the Central Depression, tree diversity is intermediate in low-stature tropical deciduous forests and high in the medium- and the highstature tropical evergreen forests (González-Espinosa et al. 2008). The high tree diversity and the variations of climatic, soil, physiographic and disturbance features in the Central Depression (Rocha-Loredo et al. 2010) foster a large variety of fruits, tubers and animals that are food sources available for Didelphis marsupialis and D. virginiana (Colchero et al. 2005; Zarza and Medellín 2005), hence contributing to a higher opossum abundance in this region.

In common species such as $D$. marsupialis and D. virginiana, an increase in population density and the expansion of local populations in modified habitats are expected; accordingly, these are known as synanthropic species (Lindenmayer et al. 2000; Markovchick-Nicholls et al. 2007; Ricotta et al. 2008; Hennessy et al. 2015). On the other hand, landscape structure is known to influence the abundance of wild species, including birds and mammals (Lindenmayer and Fischer 2007; Bruggeman et al.2010), and common species are today being seriously affected by human activities (Gaston and Fuller 2007; Gaston, 2010). Our findings indicate that these species responded differently to disturbance levels, $D$. virginiana being the species that was distributed across all levels, with no evident effect of human activities on its populations or its diversity and genetic structure (Cruz-Salazar et al. 2016). By contrast, Oceguera-González and González-Romero (2008), working in coffee plantations in Veracruz, observed a positive significant relationship between opossum abundance and forest coverage, especially for $D$. virginiana, the abundance of which was lower than that of $D$. marsupialis; this inconsistency may be explained by the particular environmental and anthropogenic conditions in each study area, which determine the quantity and availability of resources, and hence the interspecific competition and dominance of species (Begon et al. 2006).

The number of patches influenced the presence of $D$. marsupialis, i. e. a higher number of patches is associated with a higher probability of finding this marsupial species. The presence of 
Table 1. Characterization of the landscape in the Highlands and the Central Depression, and abundance of Didelphis marsupialis (Dm) and $D$. virginiana $(D v)$ by disturbance level (ND) and window $(\mathrm{V})$. PGeo = geographic location of each sampling site in the coordinate system. L1 = low disturbance, L2 = moderate disturbance, L3 = high disturbance, CP = Cerro Corral de Piedra, PA = El Aguaje village, SI = San Isidro Las Huertas village, PK = Village km 36 of the Tuxtla Gutiérrez-San Cristobal de Las Casas highway, CD = San Cristobal de Las Casas Municipal Sports Center, EC = Colegio de la Frontera Sur, San Cristobal de Las Casas, PM = San Cristobal de Las Casas Municipal Cemetery, CC = Cerro Coquelexquitzán, CA = ravine km 12 of the Tuxtla Gutiérrez-San Cristóbal de Las Casas highway, LP = La Pera, Berriozábal, RS = Rancho al Sol, $\mathrm{RP}=$ Rancho Perseverancia, TM = Tuxtla Gutiérrez campus of the Instituto Tecnologico de Monterrey, PJ = Parque Joyo Mayu, PO = Parque del Oriente, $\mathrm{Tr}=$ Tuxtla Gutierrez Regional Technology Center, NP = number of patches, ED = edge density, MSI = mean shape index, SDI = Shannon's diversity index.

\begin{tabular}{|c|c|c|c|c|c|c|c|c|c|c|}
\hline \multirow{2}{*}{ Landscape } & \multirow{2}{*}{ ND } & \multirow{2}{*}{ V } & \multicolumn{2}{|c|}{ PGeo } & \multirow{2}{*}{ NP } & \multirow{2}{*}{ ED } & \multirow{2}{*}{ MSI } & \multirow{2}{*}{ SDI } & \multirow{2}{*}{ Dm } & \multirow{2}{*}{ Dv } \\
\hline & & & Lat & Long & & & & & & \\
\hline \multirow[t]{9}{*}{ The Highlands } & L1 & $\mathrm{CP}$ & $16.71^{\circ}$ & $92.61^{\circ}$ & 162 & 273.9 & 20.1 & 1.6 & 1 & 4 \\
\hline & L1 & $\mathrm{RH}$ & $16.75^{\circ}$ & $92.68^{\circ}$ & 100 & 222.5 & 21.8 & 1.6 & 3 & 2 \\
\hline & L1 & $\mathrm{RM}$ & $16.76^{\circ}$ & $92.63^{\circ}$ & 108 & 240.1 & 21.4 & 1.6 & 0 & 5 \\
\hline & L2 & PA & $16.68^{\circ}$ & $92.59^{\circ}$ & 219 & 172.8 & 15.2 & 1.8 & 0 & 1 \\
\hline & L2 & SI & $16.69^{\circ}$ & $92.54^{\circ}$ & 88 & 186.6 & 20.3 & 1.7 & 0 & 0 \\
\hline & L2 & PK & $16.69^{\circ}$ & $92.72^{\circ}$ & 112 & 255.6 & 21.9 & 1.5 & 0 & 0 \\
\hline & L3 & PM & $16.72^{\circ}$ & $92.65^{\circ}$ & 54 & 93.9 & 18.4 & 0.9 & 0 & 0 \\
\hline & L3 & $\mathrm{CD}$ & $16.73^{\circ}$ & $92.64^{\circ}$ & 36 & 69.6 & 18.5 & 0.4 & 0 & 2 \\
\hline & L3 & $\mathrm{EC}$ & $16.71^{\circ}$ & $92.62^{\circ}$ & 127 & 223.8 & 20.6 & 2.0 & 0 & 5 \\
\hline \multirow[t]{9}{*}{ Central Depression } & L1 & $\mathrm{CC}$ & $16.72^{\circ}$ & $93.11^{\circ}$ & 218 & 305.2 & 19.6 & 1.4 & 2 & 0 \\
\hline & L1 & $\mathrm{CA}$ & $16.72^{\circ}$ & $92.92^{\circ}$ & 97 & 249.7 & 23.7 & 1.2 & 0 & 1 \\
\hline & L1 & LP & $16.87^{\circ}$ & $93.32^{\circ}$ & 84 & 160.9 & 18.3 & 0.7 & 1 & 0 \\
\hline & L2 & $\mathrm{RP}$ & $16.64^{\circ}$ & $93.01^{\circ}$ & 206 & 349.6 & 22.7 & 1.5 & 3 & 8 \\
\hline & L2 & $\mathrm{RS}$ & $16.61^{\circ}$ & $93.02^{\circ}$ & 282 & 424.3 & 22.6 & 1.4 & 0 & 3 \\
\hline & L2 & $\mathrm{TM}$ & $16.76^{\circ}$ & $93.20^{\circ}$ & 108 & 204.0 & 19.0 & 1.7 & 0 & 8 \\
\hline & L3 & $\mathrm{PO}$ & $16.76^{\circ}$ & $93.09^{\circ}$ & 80 & 138.6 & 18.8 & 0.6 & 0 & 2 \\
\hline & L3 & PJ & $16.76^{\circ}$ & $93.14^{\circ}$ & 96 & 212.7 & 21.1 & 0.9 & 0 & 14 \\
\hline & L3 & TR & $16.76^{\circ}$ & $93.17^{\circ}$ & 90 & 184.9 & 19.6 & 0.9 & 0 & 8 \\
\hline
\end{tabular}

D. marsupialis was also restrained to relatively well-preserved areas, which suggests that despite being considered a highly flexible generalist species (Adler et al. 1997; Cruz-Salazar et al. 2014), habitat loss might be influencing its populations. However, landscape indexes and disturbance levels were not related with the abundance (number of specimens captured) of this opossum species; an assessment of habitat selection and occupation should be conducted to identify metapopulations and gain a deeper insight into the dynamics of this marsupial in fragmented landscapes (Murphy et al. 2010). To some extent, D. marsupialis can be benefited by landscape fragmentation, but requires patches with low disturbance. Therefore, it is necessary to evaluate the variations of its populations through time in environments undergoing constant habitat loss and landscape fragmentation.

The abundance of $D$. virginiana was not associated with disturbance: in the Highlands, the highest relative abundance was found in areas with the lowest disturbance, but in the Central Depression the opposite occurred. This might be due to factors not considered in this study, such as variations in the availability of food and shelter and potential predators (Markovchick-Nicholls et al. 2007; Oceguera-González and González-Romero 2008). The presence of D. virginiana was 
(a)

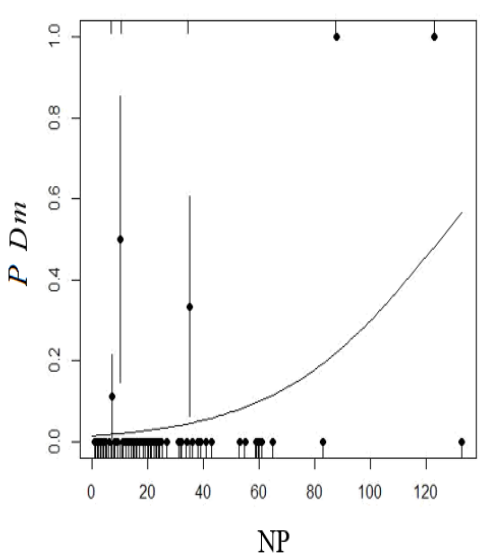

(b)

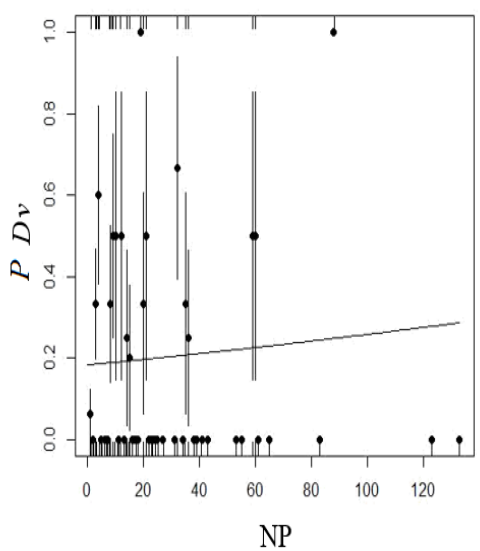

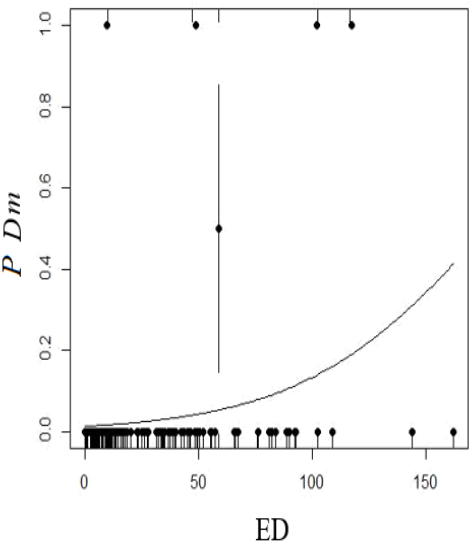
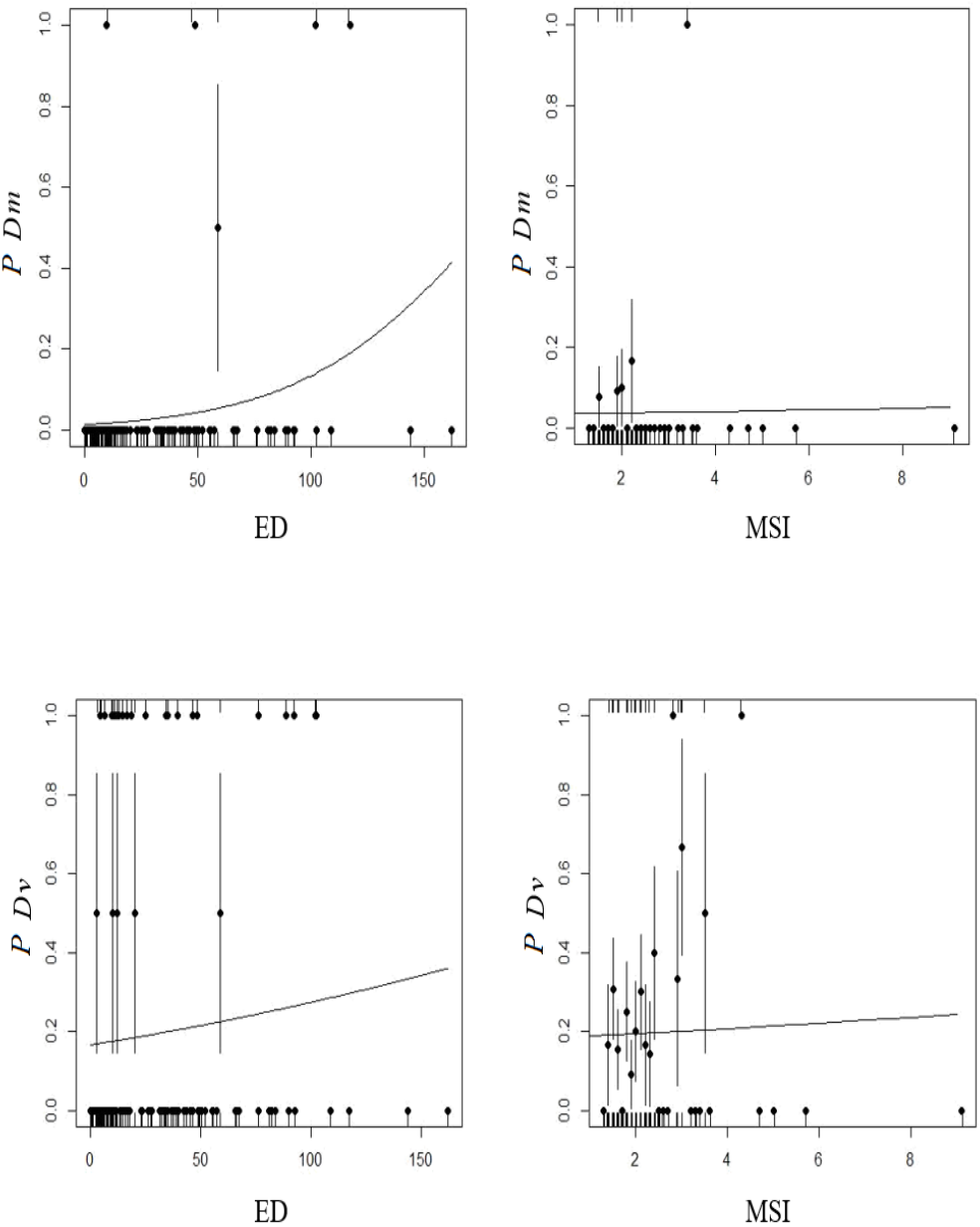

Figure 3. Multiple regression analysis of presence/absence of Didelphis marsupialis, (a) and Didelphis virginiana, (b) and landscape indices of the Highlands de Chiapas and the Central Depression, Mexico. Dm = Didelphis marsupialis, Dv= Didelphis virginiana. NP= number of patches, ED = edge density, MSI = Media Shape index, $P=$ proportion of opossum presence/absence in each class defined in the landscape.

not determined by any landscape index, suggesting that landscape composition and structure do not determine the absence or presence of this marsupial species, in agreement with Beatty et al. (2012) and Hennessy et al. (2015) who found a panmictic population with a low genetic structure in a fragmented landscape in Indiana. Kanda et al. (2009) proposed that the resources available for D. virginiana in landscapes dominated by human activities serve as a source, and natural habitats as sinks, in a metapopulation dynamics. For their part, Beatty et al. (2014) suggest that $D$. virginiana uses both anthropogenic resources and forest remnants for the survival of its populations. In this study, D. virginiana was found in all disturbance levels and showed no association with the

Table 2. Selection of generalized linear models between landscape indexes (IP) and the presence/absence of Didelphis marsupialis and $D$. virginiana in the Highlands and the Central Depression of Chiapas, measured by the Akaike Information Criterion (AIC). ED = edge density, MSI $=$ mean shape index, NP = number of patches.

\begin{tabular}{|c|c|c|c|}
\hline \multirow{2}{*}{ IP } & \multirow{2}{*}{ Modelo } & \multicolumn{2}{|c|}{ AIC } \\
\hline & & D. marsupialis & D. virginiana \\
\hline ED & Presencia/ausencia $\sim$ ED & $41.34^{*}$ & $130.89^{\mathrm{NS}}$ \\
\hline MSI & Presencia/ausencia $\sim$ MSI & $46.51^{\mathrm{NS}}$ & $132.06^{\mathrm{NS}}$ \\
\hline NP & Presencia/ausencia $\sim$ NP & $38.57^{* *}$ & $131.62^{\mathrm{NS}}$ \\
\hline
\end{tabular}


landscape attributes considered, indicating that this marsupial can be found in relatively high numbers in markedly disturbed areas with different landscape characteristics in the Highlands and the Central Depression of Chiapas.

It is worth mentioning that the possibility of the absence of a relationship between disturbance levels and opossum abundance (Didelphis spp.) being due to the scale of the study cannot be ruled out, since the species studied have high dispersal capacity and gene flow and thus can maintain a single population across a broad geographic range, even despite the presence of significant geographic barriers (Beatty et al. 2012; Hennessy et al. 2015). It is likely that an effect of disturbance on the populations of $D$. marsupialis and $D$. virginiana could be detected at a regional geographic scale; therefore, a study with a greater sampling effort, both in space and time, should be conducted in the future to evaluate these aspects.

An interesting observation is that the lower abundance of $D$. marsupialis was related to a greater abundance of $D$. virginiana; although this relationship was not significant, it is suggested that this may be the result of interspecific competition for available and potential colonization sites (e. $g$. food, shelter; Begon et al. 2006). However, our data are insufficient to evaluate this hypothesis.

This study establishes the relationship between fragmented landscapes and the presence of $D$. marsupialis, and confirms the high capacity of $D$. virginiana to maintain populations in areas with high disturbance levels during the dry season. It also contributes to the knowledge of common mammals in Mexico, particularly regarding the consequences at the population level resulting from habitat loss and landscape fragmentation by human activities.

\section{Acknowledgments}

We express our appreciation to A. Ortiz and T. A. Guillén for their support during field work. We are also grateful to the Colegio de la Frontera Sur for the resources provided for field sampling. This study is part of the Ph. D. thesis by BCS (CONACyT grant number 175336). This manuscript was translated by Maria Elena Sánchez Salazar with support of THERYA through a CONACYT grant.

\section{Literature Cited}

Adler, G. H, J. J. Arboledo, and B. L. Travi. 1997. Population dynamics of Didelphis marsupialis in Northern Colombia. Studies on Neotropical Fauna and Environment 32:7-11.

AкAIKE, H. 1974. A new look at the statistical model identification. leee Transactions on automatic control 19:716-723.

Altamirano A., A. Miranda, and C. Jiménez. 2012. Incertidumbre de los índices de paisaje en el análisis de la estructura especial. Bosque 33:171-181.

Aranda, M. 2000. Huellas y otros rastros de los mamíferos grandes y medianos de México. Comisión Nacional para el Conocimiento y Uso de la Biodiversidad. Instituto de Ecología, A. C. Xalapa, México.

Badil, M. H., and J. Landeros. 2006. Cuantificación de la fragmentación del paisaje y su relación con Sustentabilidad. International Journal of Good Conscience 2:26-38.

Beasley, J. C., W. S. Beatty, Z. H. Olson, and O. E. Rhodes. 2010. A genetic analysis of the Virginia opossum mating system: evidence of multiple paternity in a highly fragmented landscape. Journal of Heredity 101:368-373.

Beatty, W. S., J. C. Beasley, G. Dharmarajan, and O. E. Rhodes. 2012. Genetic structure of a Virginia opossum, (Didelphis virginiana) population inhabiting a fragmented agricultural ecosystem. Canadian Journal of Zoology 92:41-48.

Beatty, W. S., J. C. Beasley, And O. E. Rhodes. 2014. Habitat selection by a generalist mesopredator near its historical range boundary. Canadian Journal of Zoology 92:41-48. 
Begon M., C. R. Townsend, and J. L. Harper. 2006. Ecology: from individuals to ecosystems. Cuarta edición. Blackwell Publishing Australia.

Braunisch, V., G. Segelbacher, and A. H. Hirzels. 2010. Modelling functional landscape connectivity from genetic population structure: a new spatially explicit approach. Molecular Ecology 19:3664-3678.

Bruggeman, D. J., T. Wiegand, And N. Fernández. 2010. The relative effects of habitat loss and fragmentation on population genetic variation in the red-cockaded woodpecker (Picoides borealis). Molecular Ecology 19:3679-3691.

Cáceres, N. C., And E. L. A. Monteiro-Filho. 1998. Population dynamics of the Common opossum, Didelphis marsupialis (Mammalia, Marsupialia), in southern Brazil. International Journal of Mammalian Biology 63:169-172.

Cabello, D. R. 2006. Reproduction of Didelphis marsupialis (Didelphimorphia: Didelphidae) in the Venezuelan Andes. Acta Therologica 51:427-433.

Cervantes, F. A., J. Arcangel, Y. Hortelano-Moncada, and A. B. Borisenko. 2010. DNA barcodes effectively identify the morphologically similar common opossum (Didelphis marsupialis) and Virginia opossum (Didelphis virginiana) from areas of sympatry in Mexico. Mitochondrial DNA 21:44-50.

Colchero, F., G. O'Farril, And R. Medellín. 2005. Didelphis marsupialis (Linnaeus 1958) Tlacuache. Pp. 106108, in Los mamíferos silvestres de México (Ceballos, G., and G. Oliva, eds.). Comisión Nacional para el Conocimiento y Uso de la Biodiversidad: Fondo de Cultura Económica. Ciudad de México, México.

Cruz-Salazar, B., L. Ruiz-Montoya, D. Navarrete-Gutiérrez, E. Espinoza-Medinilla, E. Vázquez-Domínguez, and L-B. VÁzquez. 2014. Diversidad genética y abundancia relativa de Didelphis marsupialis y Didelphis virginiana en Chiapas, México. Revista Mexicana de Biodiversidad 85:251-261.

Cruz-Salazar, B., L. Ruiz-Montoya, D. Navarrete-Gutiérrez, E. Espinoza-Medinilla, E. Vázquez-Domínguez, AND L-B. VÁzquez. 2016. Genetic diversity of Didelphis virginiana related to different levels of disturbance in the Highlands and the Central Depression regions of Chiapas, Mexico. Journal of Tropical Ecology 32:146-147.

Cherem, J. J., M. E. Graipel, M. E. Menezes, and M. Soldatel. 1996. Observações sobre a biologia do gambá (Didelphis marsupialis) na Ilha de Ratones Grande, Estado de Santa Catarina, Brasil. Biotemas 9:47-56.

Cuartero, A., And A. M. Felicísımo. 2003. Rectificación y ortorrectificación de imágenes de satélite: análisis comparativo y discusión. GeoFocus 3:45-57.

ESRI (Environmental Systems Research Institute). 2011. ArcGIS Desktop: Release 10, Environmental Systems Research Institute. Redlands, U. S. A.

EVIS (Exelis Visual Information Solutions). 2013. ENVI v5.1. User's guide. Boulder, Colorado.

Fan, C., ANd S. Myint. 2014. A comparison of spatial autocorrelation indices and landscape metrics in measuring urban landscape fragmentation. Landscape and Urban Planning 121:117-128.

FaO (Food and Agriculture Organitation of the United Nations). 1996. Forest resources assessment 1990. Survey of tropical forest cover and study of change processes. FAO, Forestry Paper. 130p. Roma, Italia.

Flick, T., S. Feagan, And L. Fahrig. 2012. Effects of landscape structure on butterfly species richness and abundance in agricultural landscapes in Eastern Ontario, Canada. Agriculture, Ecosystems and Environment 156:123-133.

Gardner, A. L. 1973. The systematics of the genus Didelphis (Marsupialia: Didelphidae) in North and Middle America. Special Publications the Museum Texas Tech University 4:1-81.

Garmendia, A., V. Arroyo-Rodríguez, A. Estrada, E. J. Naranjo, and K. E. Stoner. 2013. Landscape and patch attributes impacting medium- and large-sized terrestrial mammals in a fragmented rain forest. Journal of Tropical Ecology 29:331-344.

Gaston, K. J. T. M. Blackburn, J. J. D. Greenwood, R. D. Gregory, R. M. Quinn, and J. H. Lawton. 2000. Abundance-occupancy relationships. Journal of Applied Ecology 37:39-59.

Gaston K. J., AND R. A. Fuller. 2007. Biodiversity and extinction: losing the common and the widespread. Progress in Physical Geography 31:213-225.

Gaston, K. J. 2010. Valuing common species. Ecology 327:154-155. 
Gillette, L. N. 1980. Movement patterns of radio-tagged opossums in Wisconsin. American Midland Naturalist 104:1-12.

González-Espinosa, M., N. Ramírez-Marcial, G. Méndez-Dewar, L. Galindo-Jaimes, and D. Golicher. 2005. Riqueza de especies de árboles en Chiapas: variación espacial y dimensiones ambientales asociadas al nivel regional. Pp. 81-125, in Diversidad Biológica en Chiapas (González-Espinosa, M., N. Ramírez-Marcial, AND L. Ruiz-Montoya, eds.). ECOSUR, COCyTECH, Plaza y Valdez Editores. Ciudad de México, México.

González-Espinosa, M., N. Ramírez-Marcial, and J. M. Rey-Benayas. 2008. Variación Espacial de la diversidad arbórea de Chiapas: patrones regionales y jerarquía de factores determinantes. Pp. 147-166, in Ecología, manejo y conservación de los ecosistemas de montaña en México (Sánchez-Velásquez, L. R., J. Galindo-González, and F. Díaz-Fleischer, eds.). Mundi-Prensa México, S. A. de C. V. Ciudad de México, México.

Gorresen, P. M., ANd M. R. Wiluig. 2004. Landscape responses of bats to habitat fragmentation in Atlantic Forest of Paraguay. Journal of Mammalogy 85:688-697.

Hennessy, C., C.-C. Tsai, J. C. Beasley, W. S. Beatty, P. A. Zollner, and O. E. Rhodes. 2015. Elucidation of population connectivity in synanthropic mesopredators: using genes to define relevant spatial scales for management of raccoons and Virginia opossums. The Journal of Wildlife Management 79:112-121.

Hughes, J., K. Goudkamp, D. Hurwood, M. Hancock, and S. Bunn. 2003. Translocation causes extinction of a local population of the freshwater shrimp Paratya australiensis. Conservation Biology 17:10071012.

INEGI (Instituto Nacional de Estadística y Geografía). 2012. Guía para la interpretación de cartografía. Uso del suelo y vegetación. Escala 1:250000. Serie IV. Ciudad de México, México.

INEGI (Instituto Nacional de Estadística y Geografía). 2013. Manual de usuario Sistema de Interpolación de Alturas Geoidales, v1.1. Aguascalientes, México.

Kanda, L. L., T. K. Fuller, P. R. Sievert, and K. D. Friedland. 2005. Variation in winter microclimate and its potential influence on Virginia opossum (Didelphis virginiana) survival in Amherst, Massachusetts. Urban Ecosystems 8:215-225.

Kanda, L. L., T. K. Fuller, P. R. Sievert, and R. L. Kellogg. 2009. Seasonal source-sink dynamics at the edge of a species' range. Ecology 90:1574-1585.

Kelly, M. J., And T. CARo. 2003. Low density of small mammals at Las Cuevas, Belize. Mammalian Biology 68:372-386.

Lambert, T. D., J. R. Malcolm, ANd B. L. Zimmerman. 2005. Variation in small mammal species richness by trap height and trap type in southeastern Amazonia. Journal of Mammalogy 86:982-990.

Lindenmayer, D. B., R. C. Lacy, and M. L. Pope. 2000. Testing a Simulation model for Population Viability Analysis. Ecological applications 10:580-597.

Lindenmayer D., R. J. Hobbs, R. Montague-Drake, J. Alexandra, A. Bennett, M. Burgman, P. Cale, A. Calhoun, V. Cramer, P. Cullen, D. Driscoll, L. Fahrig, J. Fischer, J. Franklin, Y. Haila, M. Huter, P. Gibbons, S. Lake, G. Luck, C. MacGregor, S. Mcintyre, R. Mac N., A. Manning, J. Miller, H. Mooney, R. Noss, H. Possingham, D. Saunders, F. Schmiegelow, M. Scott, D. Simberloff, T. Sisk, G. Tabor, B. Walker, J. Wiens, J. Woinarski, And E. Zavaleta. 2008. A checklist for ecological management of landscapes for conservation. Ecology Letters 11:78-91.

LindenmaYeR, D. B., AND J. Fischer. 2007. Tackling the habitat fragmentation pancheston. Trends in Ecology and Evolution 22: 111-166.

Markovchick-Nicholls, L., H. M. Regan, D. H. Deutschman, A. Widyanata, B. Martin, L. Noreke, and T. A. Hunt. 2007. Relationships between human Disturbance and Wildlife Land Use in Urban Habitat Fragments. Conservation Biology 22:99-109.

McAlpine, C. A., M. E. Bowen, G. C. Smith, G. Gramotnev, A. G. Smith, A. L. Cascio, W. Goulding, and M. MARon. 2015. Reptile abundance, but not species richness, increases with regrowth age and 
spatial extent in fragmented agricultural landscapes of Eastern Australia. Biological Conservation 184:174-181.

McManus, J. J. 1974. Didelphis virginiana. Mammalian Species 40:1-6.

Medina-Romero, M., R. Goyenechea, and J. Castillo-Cerón. 2012. Phylogenetic measures applied to the conservation of Mexican marsupials. Revista Mexicana de Biodiversidad 83:1216-1220.

Miranda, F., and Hernández X. 1963. Los tipos de vegetación de México y su clasificación. Boletín de la Sociedad Botánica de México 28:29-179.

Murphy, M. A., R. Dezzani, D. S. Pilliod, And A, Storfers. 2010. Landscape genetics of high mountain frog metapopulations. Molecular Ecology 19:3634-3649.

Naranjo, P. E., C. Lorenzo M., and A. Horváth. 2005. La diversidad de mamíferos en Chiapas. Pp. 221264, in Diversidad Biológica en Chiapas (González-Espinosa, M., N. Ramírez-Marcial, AND L. RuizMontoya, eds.). ECOSUR, COCYTECH, Plaza y Valdés, S. A. de C. V. Ciudad de México, México.

Naranjo, P. E., C. Lorenzo M., A. Horváth, A. Riechers P., E. Espinoza M., J. Bolaños C., R. Vidal L. and E. Cruz A. 2013. Diversidad y conservación de los mamíferos. Pp. 351-361, in La Biodiversidad en Chiapas (Comisión Nacional para el Conocimiento y Uso de la Biodiversidad, eds.). Comisión Nacional para el Conocimiento y Uso de la Biodiversidad, Gobierno del Estado de Chiapas. Chiapas, México.

Oceguera-González, A., And A. González-Romero. 2008. Hábitos alimentarios y reproducción de dos especies de tlacuache en cafetales del centro de Veracruz, México. Pp. 295-309, in Avances en el estudio de los mamíferos en México II (Lorenzo, C., E. Espinoza, and J. Ortega, eds.). Editora Alternativa Periodística, S. A de C. V. Ciudad de México, México.

OrJuela, C. O. J., ANd G. Jiménez. 2004. Estudio de la abundancia relativa para mamíferos en diferentes tipos de coberturas y carretera, Finca Hacienda Cristales, Área Cerritos-La Virginia, Municipio de Pereira. Universitas Scientiarum 9:87-96.

Ramírez-Albores, J. E. 2010. Avifauna de sitios asociados a la selva tropical en la depresión central de Chiapas, México. Acta Zoológica Mexicana 26:539-562.

Ramírez-Marcial, N., M. González-Espinosa and D. Williams-Linera. 2001. Anthropogenic disturbance and tree Diversity in Montane Rain Forests in Chiapas, México. Forest Ecology and Management 154:311-326.

Ramírez-Pulido, J., N. González-Ruiz, A. L. Gardner and J. Arroyo-Cabrales. 2014. List of recent land mammals of México 2014. Special Publications, Museum of Texas Tech University. Museum of Texas Tech University.

Rempel, R. S., D. Kaukinen, and A. P. Carr. 2012. Patch Analyst and Patch Grid. Ontario Ministry of Natural Resources. Centre for Northern Forest Ecosystem Research, Thunder Bay, Ontario. http://www. cnfer.on.ca/SEP/patchanalyst/Patch5_0 Install.htm (reviewed 21/07/2016).

Ricotta, C., S. Godefroid, and L. Celesti-Grapow. 2008. Common species have lower taxonomic diversity. Diversity and Distributions 14:530-537.

Rocha-Loredo, A. G., N. Ramírez-Marcial, and M. González-Espinosa. 2010. Riqueza y diversidad de árboles del bosque tropical caducifolio en la depresión central de Chiapas. Boletín de la Sociedad Botánica de México 87:89-103.

Schooley, R. L., AND L. C. Branch. 2011. Habitat quality of source patches and connectivity in fragmented landscapes. Bidodiversity Conservation 20:1611-1623.

Spear S. F., N. Balkenhol, M-J. Fortin, B. H. Mcrae, and K. Scribner. 2010. Use of resistance surfaces for landscape genetic studies: considerations for parameterization and analysis. Molecular Ecology 19:3576-3591.

Sunquist, M. E., S. N. Austad, ANd F. Sunquist. 1987. Movement patterns and home range in the common opossum (Didelphis marsupialis). Journal of Mammalogy 68:173-176.

Team, R. C. 2013. R: a language and environment for statistical computing. R foundation for statistical computing, Vienna, Austria. 
Tlapaya, L., And S. Gallina. 2010. Cacería de mamíferos medianos en cafetales del centro de Varacruz, México. Acta Zoológica Mexicana 26:259-277.

WRIGHT, J. F., M. S. BURT, AND V. L. JACKSON. 2012. Influences of an urban environment on home range and body mass of Virginia opossums (Didelphis virginiana). Northeastern Naturalist 19:77-86.

Zarza, H., and R. A. Medellín. 2005. Didelphis virginiana (Kerr 1792) Tlacuache. Pp. 108-110, in Los mamíferos silvestres de México (Ceballos, G., and G. Oliva, eds.). Comisión Nacional para el Conocimiento y Uso de la Biodiversidad: Fondo de Cultura Económica. Ciudad de México, México

Submitted: May 14, 2016

Reviewed: July 17, 2016

Accepted: August 6, 2016

Associated editor: Sergio Ticul Alvarez Castañeda

Appendix 1. Indexes selected to characterize landscape structure and configuration.

\begin{tabular}{lcll}
\hline \multicolumn{1}{c}{ Landscape index } & Acronym & \multicolumn{1}{c}{ Property } & \multicolumn{1}{c}{ Definition } \\
\hline Number of patches & NP & Degree of fragmentation & $\begin{array}{l}\text { Total number of fragments and number of fragments in each } \\
\text { class }\end{array}$ \\
$\begin{array}{l}\text { Edge Density } \\
\text { Mean Shape Index }\end{array}$ & ED & $\begin{array}{l}\text { Edge feature } \\
\text { Complexity of fragment } \\
\text { shape } \\
\text { Landscape diversity }\end{array}$ & $\begin{array}{l}\text { Total edge perimeter relative to landscape area } \\
\text { Calculates the mean shape by class level and landscape }\end{array}$ \\
Shannon diversity index & SDI & $\begin{array}{l}\text { Estimates heterogeneity from probabilities. The value } \\
\text { represents the probability that two randomly selected items } \\
\text { could be different }\end{array}$ \\
\hline
\end{tabular}

